\title{
Career experts' conceptions of innovation in career development
}

\author{
Jaana Kettunen ${ }^{1}$ (D) \\ Received: 5 December 2020 / Accepted: 21 September 2021 \\ (c) The Author(s) 2021
}

\begin{abstract}
This article reports the findings from a phenomenographic investigation into career experts' conceptions of innovation in career development. The results show that conceptions of innovation in career development varied from (1) initiating service, (2) developing demographic-based programmes, (3) professionalising the sector to (4) exploiting cross-sectoral synergies. The findings give us a more profound understanding of critical aspects that may have an important role in improving innovation in career development.
\end{abstract}

Keywords Career development · Innovation · Phenomenography

\section{Résumé}

Conceptions d'experts de l'orientation des innovation dans le domaine du développement de carrière Cet article rapporte les résultats d'une étude phénoménographique sur les conceptions des expert·e·s de carrière en matière d'innovation dans le développement de carrière. Les résultats montrent que les conceptions de l'innovation dans le développement de carrière varient de (1) l'initiation du service, (2) le développement de programmes pour des populations spécifiques, (3) la professionnalisation de secteurs à (4) l'exploitation des synergies intersectorielles. Les résultats nous donnent une compréhension plus profonde des aspects critiques qui peuvent avoir un rôle important dans l'amélioration de l'innovation dans le domaine du développement de carrière.

\section{Zusammenfassung}

Die Vorstellungen von Karriereexperten über Innovation in der Karriereentwicklung Dieser Artikel berichtet über die Ergebnisse einer phänomenographischen Untersuchung zu den Vorstellungen von Laufbahn-Experten über Innovation in Programmen der Laufbahnentwicklung. Die Ergebnisse zeigen, dass die Vor-

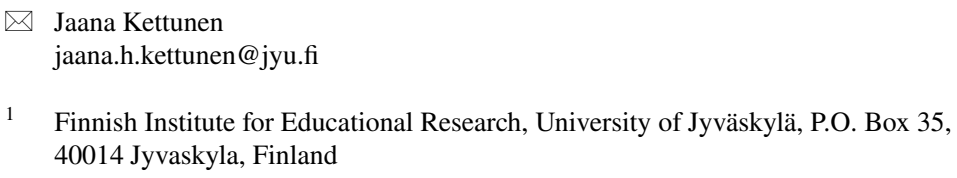


stellungen von Innovation in der Laufbahnentwicklung von (1) der Initiierung von Dienstleistungen, (2) der Entwicklung von Programmen auf Basis demografischer Informationen, (3) der Professionalisierung des Sektors bis hin zu (4) der Nutzung von sektorübergreifenden Synergien variieren. Die Ergebnisse geben uns ein tieferes Verständnis für kritische Aspekte, die eine wichtige Rolle bei der Verbesserung der Innovation in der Laufbahnentwicklung spielen können.

\section{Resumen}

Concepciones de los expertos sobre la innovación en el desarrollo de la carrera Este artículo presenta los resultados de una investigación fenomenográfica sobre las concepciones de los expertos en carreras profesionales sobre la innovación en el desarrollo de la carrera. Los resultados muestran que las concepciones de la innovación en el desarrollo de la carrera varían desde (1) la iniciación del servicio, (2) el desarrollo de programas de base demográfica, (3) la profesionalización del sector hasta (4) el aprovechamiento de las sinergias intersectoriales. Los resultados nos permiten comprender más profundamente los aspectos críticos que pueden tener un papel importante en la mejora de la innovación en el desarrollo de la carrera.

\section{Introduction}

The world of work has changed considerably in recent decades as a consequence of multiple factors that include globalisation, digitalisation and automation (e.g. Cedefop, 2016; Organization for Economic Co-Operation and Development [OECD], 2019; Patton \& McMahon, 2015). Traditional occupations and work methods are changing fast (e.g. Brynjolfsson \& McAfee, 2014; Frey \& Osborne, 2017), and individuals are increasingly required to cope with serial work and life transitions, including periods of under- or over-employment, multiple career changes and returns to education (e.g. Amundson, 2005; Hirschi, 2018; McMahon \& Tatham, 2008; OECD, 2019) as previously non-standard forms of work-temporary, shortterm and agency-based work and self-employment-become more widespread (e.g. Dølvik \& Steen, 2018; International Labour Organization [ILO], 2016; Eurofound, 2017). In light of these changes, the individuals must embrace continuous learning and flexibility to maintain their employability and create their own opportunities (e.g. Amundson, 2005; Savickas et al., 2009).

Career development services are perceived to be one accepted way of assisting individuals to make well-informed and realistic decisions about education, training and occupational choices and acquire lifelong career management skills (Cedefop, 2011; European Council, 2004, 2008; OECD, 2004). In this context of rapid change, the career development sector must innovate and evolve to meet the challenges of this dynamic connected economy (e.g. Barnes et al., 2020; Lee \& Johnston, 2001; OECD, 2004). Calls to enhance professionalism within the career development sector are increasing (e.g. Cedefop, 2009; OECD, 2010; Sienkiewicz, 2012). However, the OECD (2004) and Cedefop (2009) have found little evidence of systematic and continuous professional development for career professionals. Over the past decades, 
public services have been among the main adopters of information and communication technologies (e.g. Van Reenen et al., 2010), and technology is having an impact on traditional career guidance services. As interactive technology continues to grow in popularity and influence, it is increasingly necessary to align new technologies more closely with career services and associated professional practices (e.g. Bimrose et al., 2010; Kettunen, 2017; Sampson et al., 2020).

There is increasing recognition that innovation is one of the a key means by which public services can become more effective, more efficient or more legitimate (Windrum \& Koch, 2008). As countries differ widely in the development and delivery of career services, the idea of innovation is necessarily relative, where career development services are scarce or non-existent, for example, almost any initiative can be regarded as innovative (Zelloth, 2009). In general, innovation can be defined as '[...] the successful introduction of something new and useful, for example, introducing new methods, techniques, or practices or new or altered products and services' (Dasgupta \& Gupta, 2009, p. 205). According to Van de Ven (1986, p. 2), however, 'as long as the idea is perceived as new to the people involved, it is an "innovation", even though it may appear to others to be an imitation or something that exists elsewhere'. In any event, innovation is about problem-solving and addressing challenges in life and society that are complex, multi-faceted and require a creative approach (Hautamäki \& Oksanen, 2016). Although it seems that for many public services, change and innovation are mainly top-down, planned and formalised processes (e.g. European Commission, 2011; Hartley, 2005), recent literature points to the rise of collaborative innovation in the public sector (e.g. Bommert, 2010; Torfing, 2019). This multi-actor collaboration is envisaged as taking place inside public administrations, between members of different public bodies, but also with private partners. Many scholars have highlighted that complex problem-solving benefits from diverse perspectives (Van der Vegt \& Janssen, 2003), multi-professional collaboration (Kettunen \& Felt, 2020) and engagement with multiple stakeholders (e.g. Barns et al., 2020; Pittaway et al., 2004), integrating diverse knowledge bases, behaviours and ways of thinking.

In career development contexts, innovation may involve new theories, methods, services, practices, techniques, tools, or institutional structures to produce a significant change in career service delivery. For example, technological innovations like the expansion of Internet, mobile phone and social media use present new opportunities for people to give and receive career support (e.g. Flederman \& Watts, 2014; Hooley et al., 2010; Kettunen et al., 2015; Sampson et al., 2020). In an analysis of career theory and practice worldwide, Amundson (2005) identified theoretical innovations grounded in constructivism, systems theory, action theory and fragmentary developments highlighting the importance of paradoxical thinking. Innovations in career development practice included a greater emphasis on active engagement, more holistic methods and an increased emphasis on counselling efficacy (Amundson, 2005). Drobnic (2019) noted that recent innovations in career guidance on labour market developments have driven an increased emphasis on the career guidance client's autonomy, which necessarily positions the counsellor in a non-authoritative role. According to Barns et al. (2020), new and innovative guidance practices and tools aim to provide seamless service delivery across the individual's life 
course. This more integrated lifelong approach emphasises user centrality, individually tailored service provision and enhanced networking based on digital technologies (Barns et al., 2020).

Innovation studies in the area of career development are rare and there is an apparent research gap that this study aims to narrow. The present study explores innovation in the career development sector as perceived by international career development experts. The aim was to identify and describe variation of qualitatively different conceptions of the phenomenon. The study was guided by the following research questions: (1) What are career development experts' conceptions of innovation in career development? and (2) What are the critical aspects that differentiate the qualitatively varying ways of understanding career development innovation? The ultimate aim of describing the variation in conceptions is to expand understanding of the critical aspects that may play important role in improving innovation in career development.

\section{Methods}

The study employed a phenomenographic approach, which investigates individual variations in experiencing or understanding a given phenomenon (Bowden \& Walsh, 2000; Marton, 1981; Marton \& Booth, 1997). Phenomenography assumes that a particular phenomenon can be experienced in only a limited number of ways, and that these are logically related. The primary outcome of any phenomenographic analysis is a structured set of logically related categories describing qualitative variations in ways of experiencing or understanding the phenomenon in question a collective level (Marton, 1986). According to Marton and Booth (1997), these categories of description should meet the following three quality criteria: (1) each category should describe a distinct way of conceiving the phenomenon, (2) the logical relationship between categories should be hierarchically represented, and (3) variation across the sample should be described by a limited number of parsimonious categories. Steps taken to meet these criteria in the present study are described in the data analysis section.

Previous phenomenographic studies of career development have explored issues that include career practitioners' conceptions of social media (Kettunen et al., 2013); ethical practice in social networking (Kettunen \& Makela, 2019); leadership and management in guidance and counselling networks (Nykänen, 2011); the role of ICT in relation to national guidance policies (Kettunen et al., 2016); and challenges in implementing ICT in career services (Kettunen \& Sampson, 2019).

\section{Participants and the study context}

The participants in this study were designated governmental and non-governmental representatives from 33 countries attending the International Symposium for Career Development and Public Policy (hereafter ICCDPP Symposium). This ninth Symposium invited delegates to share their experiences in the development of national 
strategies for career development and to explore opportunities for ongoing networking (Watts et al., 2014) to harness the benefits of sharing international practice and policy development (Kettunen \& Sampson, 2019; Watts, 2005). Respondents represented policymakers, policy developers and influencers, national authorities, international institutions, managers of national career guidance services, leaders of national and international associations of guidance practitioners, employers representatives, private enterprises and researchers and trainers of career practitioners, thus covering the entire career development community. National teams that answered the questionnaire consisted of 134 delegates, of whom 71 were women and 63 were men; 37 were government employees in ministries of education and employment; 40 were civil servants working in the education and labour sectors; 52 represented national guidance forums, centres or associations; and 5 worked in the private sector. The data collection was a part of the preparation for the symposium in Tromssa, Norway, in June 2019, which addressed issues of access, integration and innovation in an uncertain future.

\section{Data collection}

The survey data were collected using open-ended questions that asked participants to provide written responses at a national level as country teams. Since the primary focus was on capturing the richness of the collective experiences of a relatively large number of participants located around the world, the open-ended survey method constituted an appropriate means of data collection for this phenomenographic research. Although the written responses provided little or no opportunity for follow-up questions, this approach has been successfully applied in a number of previous phenomenographic studies (e.g. Hathaway \& Fletcher, 2018; Kettunen \& Sampson, 2019; Loughland et al., 2002; Tynjälä, 1997).

The Symposium coordination unit emailed a link to the online survey in November 2018, and responses (one response per team) were received from the following 33 country teams: Austria, Cambodia, Canada, Chile, Croatia, Denmark, Egypt, England, Estonia, Finland, France, Germany, Ghana, Hungary, India, Ireland, Japan, Korea, Kosovo, Luxembourg, Mongolia, Norway, Qatar, Scotland, Serbia, Singapore, Slovenia, Sri Lanka, Switzerland, Syria, the Netherlands, Tunisia and the United States. Each country delegation of one to six members was asked to provide a country-specific response to the following four open-ended questions: (1) What are the key innovations or ways that career development programmes and services have changed over the last 10 years? (2) How do national policies and initiatives, where they exist, ensure and support the development of innovation in career development services provision? (3) What new, innovative and promising interventions in career development programmes and services is your country planning for the future? and (4) How is the training and continuing professional development (CPD) of careers professionals encouraging innovation and taking account of new evidence as well as changes in technology and the labour market? Responses ranged in length from half a page to five pages, averaging two pages. In total, the data yield 62 pages of text (A4, single spaced). 


\section{Data analysis}

Data analysis was conducted using a phenomenographic approach (Åkerlind, 2005b; Kettunen \& Tynjälä, 2017; Marton \& Booth, 1997; Marton \& Pong, 2005), following the guidelines and examples provided by Åkerlind (2005a, 2005b), Bowden (2000a), and Bowden and Green (2005). The analysis involved three phases. The first phase sought to identify and describe conceptions of career development innovation in general terms, 'bracketing' presuppositions and personal understandings to maintain an open mind (Ashworth \& Lucas, 2000; Marton \& Booth, 1997). The written responses were considered as a whole and re-read a number of times to identify underlying foci and intentions expressed in them. To improve accuracy in the interpretation, the transcript was read as a whole or in large sections (Åkerlind et al., 2005). To identify key relationships and distinct characteristics, subsequent readings focussed on similarities and differences in the meanings expressed. By comparing and contrasting these similarities and differences, a draft set of descriptive categories of collective meaning was gradually developed, defined and named.

The second phase of the analysis sought to delineate the logical relationships among the various categories. Themes that ran through and across the data were identified and used to structure the relationships within and between categories (Åkerlind, 2005a). The aim was to distinguish between more and less complex ways of seeing the phenomenon (Åkerlind, 2005a; Marton \& Booth, 1997), to highlight its different aspects. Throughout this phase, the initial categories of description were further elaborated, fixed and defined according to the characteristic features of each category, with constant reference to the data.

To ensure robustness, the data were initially analysed by the author, who then sought a second opinion from a colleague. The categories and their structures were discussed and revised during several such meetings, so ensuring that the interpretations were valid. Research colleagues acted as critical friends, probing the category candidates and their critical aspects and seeking justifications from within the transcripts. As Bowden (2000b) emphasised, this group process makes it less likely that analysis will cease prematurely, and helps to ensure loyalty to the data minimising the researcher's individual perspective and potential for bias. Iterative re-reading and re-drafting continued until saturation - that is, until the process failed to produce any further significant changes in the categories of description (Bowden \& Green, 2010).

The final phase of analysis sought to ensure that the categories of description met the quality criteria mentioned earlier, as specified by Marton and Booth (1997): (a) that each category described a distinct way of experiencing the phenomenon; (b) that the logical relationships between categories were hierarchical; and (c) that in describing variation across the sample, the categories were parsimonious and limited in number.

\section{Results}

Analysis of the data revealed four distinct categories of description that reflected career development experts' conceptions of innovation in career development (Table 1). Innovation in career development was conceived as: (1) initiating service, 
(2) developing demographic-based programmes, (3) professionalising the sector, and (4) exploiting cross-sectoral synergies. The differences between the categories appeared along six dimensions of variation that included: innovative initiatives, development emphasis, rationale for developing ICT use, delivery of professional development and realisation of career education.

Each category is described in more detailed below, along with excerpts from relevant written responses to illustrate key aspects of the categories. It is important to note that this categorization represents collective rather than individual or countryspecific conceptions of innovation in career development.

\section{Description of the categories}

\section{Category 1: Initiating services}

In this first category, innovation is conceived as initiating career development services. Innovative initiatives were seen as desired with a general ambition to innovate. Focus on development was placed on setting up services that have been lacking as a result of political instability or the short history of career services in that country. A key rationale for developing the use of ICT was to promote the value of career development and related services by providing more information to the public about what professional careers support can offer them and what to look for when seeking access.

Projects have a fundamental ambition to innovate and develop something new. [National body] is piloting career guidance and counselling services for selected schools.

[Country] is planning to develop online platform to promote career guidance and counselling.

In this category, country teams indicated that there was an acknowledged need and/or initial plans for creating continuing training specific to career services. Decisions about how such training would be delivered were not yet planned. Here countries had started piloting career education curriculum in selected schools or educational institutions.

The state will set up a continuing training program for career guidance counsellors.

The technical education in [country] started to pilot a career development curriculum.

\section{Category 2: Developing demographic-based programmes}

In this second category, innovation was conceived as developing demographic-based career development programs. Innovation was mainly initiated from the top-down by public organisations (i.e. based more or less on political decision-making). Focus on development was placed on designing career-related programmes that meet the specific needs or requirements of a particular group of people. A key rationale for 


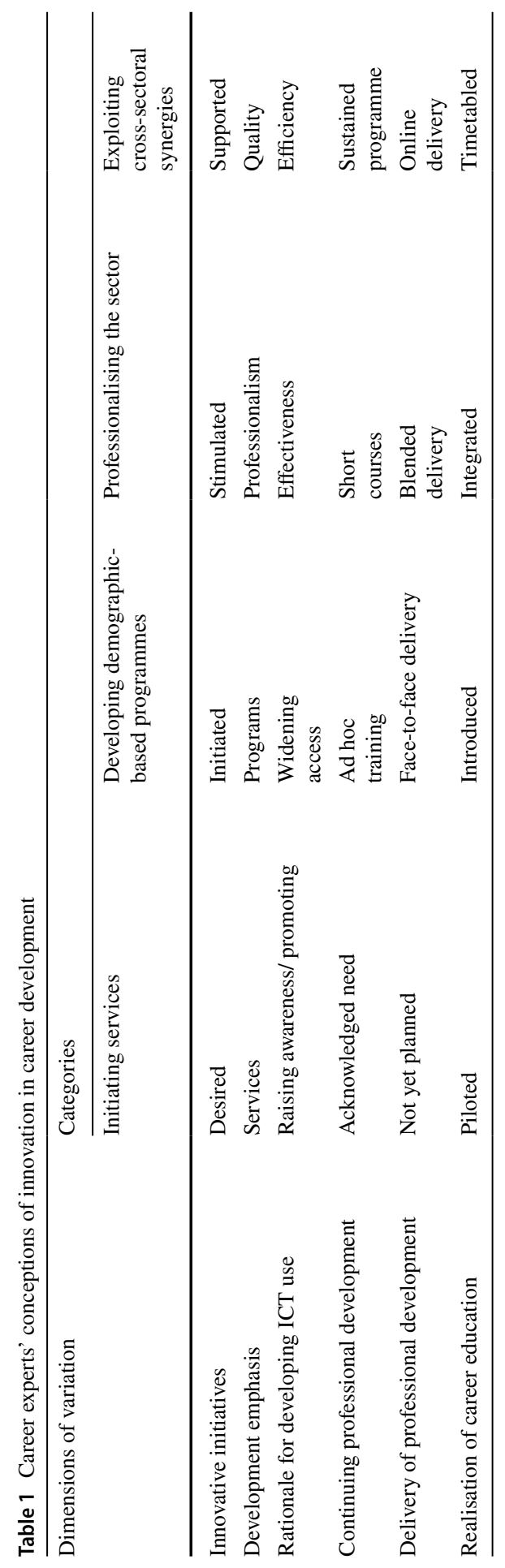


developing the use of ICT was to widen and extend access to career-related information, principally through digital platforms and mobile application.

Currently the innovation in career development services is very much related, and/or the result of national policies and initiatives.

Investments in demographic-based programs responding to the needs of an ageing population, foreign trained professionals, refugee newcomers and indigenous youth have driven new career development approaches, methodologies and service delivery models.

Access to information has been greatly facilitated with the creation of platforms and digital resources ...

In this category, continuing professional development training is offered on an ad hoc basis but remained confined to a limited number of courses and programmes which take place in face-to-face settings. Career guidance program and/ or activities were introduced as part of the to school curriculum, but participation in these programmes and/or activities was voluntary rather than mandatory.

There were ad hoc trainings for a small number of teachers in schools and for those employed as career centre staff.

School-based career guidance program and activities are introduced to school curricula.

\section{Category 3: Professionalising the sector}

In this third category, innovation in career development was conceived as professionalising the sector. Innovation initiatives were stimulated by top-down demands empowering bottom-up innovation among key regional actors. Development focuses on career practitioners' professionalism in terms of their training and qualifications. Country teams indicated that professional competencies and competency standards were under revision or would be revised. A key rationale for developing the use of ICT was to improve the effectiveness of the services provided by extending opportunities to provide distance career services, using synchronous real-time phone- or chat-based communication.

The counties were given quite a lot freedom . . . and local innovation was stimulated.

Professionalisation of all those involved in career development is critical. The introduction of a new higher apprenticeship scheme for career development will offer a new professional pathway, making training more accessible for new practitioners. This is specifically important as the sector is currently experiencing a skills shortage.

Career development professional competencies and competency standards will be expanded and revised.

The main driver regarding the governance has been the aim to make effective use of resources ... [This includes] the use of several digital solutions 
to support citizens career development (chat service online; the use of digital learning environments).

Here continuing professional development and short or refresher courses on new information or new methods were conducted on a regular basis. Beyond the traditional face-to-face model, these courses were delivered in blended mode combining face-to-face learning activities and online learning components. Career development education was now integrated in the curriculum and delivered through series of themes taught across different subjects.

Constant refresher training has been conducted.

The blended CPD approach ... offers an opportunity for practitioners to enhance their digital skills.

Career guidance became an integral part of the [country name] curriculum framework, involving its offer in the curriculum.

\section{Category 4: Exploiting cross-sectoral synergies}

In this forth category, innovation in career development was conceived as exploiting cross-sectoral synergies. Innovative initiatives were supported to achieve common strategic development goals at country level by enhancing cross-sectoral collaboration and coordination and multi-stakeholder engagement. Development focussed on quality issues in career development sector to ensure the delivery of high-quality services. A key rationale for developing ICT use was to improve the quality and efficiency of career development services through more efficient use of resources and data, notably through matching technology, artificial intelligence and machine learning. Emphasis was also placed on finding new and creative ways of improving services by combining human knowledge and experience with machine-generated data and tools.

National programmes also support innovation in the delivery of career development services...

[National body] has been tasked to lead the development of a national, crosssectoral quality framework. The process includes all stakeholders and aims to make the framework a tool for quality development and assurance and for government.

To improve the quality of private employment services, PES certifies whether they satisfy the minimum standards.

A ChatBot system that can respond to repetitive and typical questions can provide an efficient job counselling service.

In this category, a sustained programme of continuing professional development was provided based on identified training needs and national priorities for policy and practice. Unlike previous categories, training was now offered and can be accessed fully online. Here career development education is delivered as a standalone and timetabled subject within the curriculum, facilitated by teachers, careers professionals, teaching support staff and other external partners that include employers and 
further and higher education providers. Participants highlight that developing students' career management skills helps them to better understand the job market, relate school-based learning to the workplace and develop their personal strengths to be successful in developing their careers.

Continuing professional development is based on national guidance policy and practice priorities and training needs analysis.

[Continuing profession development] training courses are not provided only in a face-to-face form, but where possible and suitable, e-training courses (including video training modules) are used.

Career information advice and guidance is delivered within the national curriculum.

\section{Relationship between the categories}

The descriptive categories were delimited from each other and organised hierarchically according to the dimensions of variation that emerged from the data. Due to the hierarchical nature of the categories, some conceptions can be regarded as more complete and more complex than others (Åkerlind, 2005a).

Across the categories, the degree of emphasis on innovative initiatives shifted from desired to supported. In category 1, where innovation was conceived as initiating career development services, ambition and desire for innovative service initiation was expressed. In categories 2 and 3, where innovation in career development is conceived as developing demographic-based programs and professionalising the sector, innovative initiatives were initiated (category 2) in top-down manner and stimulated by empowering bottom-up processes (category 3 ). In the most complex category 4 , innovative initiatives were supported by cross-sectoral collaboration and coordination and strategic stakeholder engagement.

Development emphasis also differed across categories. In category 1 , development was mainly focussed on setting up currently non-existent services. In category 2 , the emphasis shifted from services to developing demographic-based programmes. Category 3 marked a change, as the emphasis shifted from service and programme development to professionalism. In the most complex category 4 , where the innovation in career development was conceived as exploiting cross-sectoral synergies, the development emphasis expanded on quality issues in the provision.

Shifts in the rationale for developing ICT use ranged from promoting and raising awareness of career development and related services to improving quality and efficiency. In the least complex categories, the key rationale for developing ICT use was raising awareness about career services (category 1) and widening access to guidance and information (category 2). A turning point occurred in category 3, where innovation in career development was conceived as professionalising the sector, as this marked a change to providing more effective client services. In the most complex category, the potential to improve the efficiency of career services provided the key rationale for developing ICT use.

Regarding continuing professional development, the transition across the categories was from acknowledged need to delivering sustained online programmes. In 
essence, the difference between category 1 and the other categories related to newly acknowledged training needs, whereas the more complex categories addressed the nature of training offered. A shift from acknowledged need to ad hoc training was discerned in category 2, where the innovation in career services is conceived as developing demographic-based programmes. In the most complex categories, the continuing professional development extended to short courses (category 3) and emphasised sustained programmes (category 4) based on identified training needs and national policy and practice priorities.

The delivery of professional development also varied across categories. In category 1 , where innovation in career development was conceived as service initiation, the decisions how such training would be delivered were not yet planned. In category 2, professional development was delivered in face-to-face settings. There was a visible turning point in category 3 , where innovation in career development is conceived as professionalising the sector, marking a change from face-to face delivery mode to combination of face-to-face and online, blended delivery. In category 4, a further important shift was observed as training was offered and delivered entirely online.

Realisation of career education ranged from pilot initiatives to timetabled subjects. In the least complex categories, selected schools or institutions were piloting career education (category 1) and obligatory activities were introduced to school curriculum (category 2). A turning point was in category 3 , where innovation in career development is conceived as professionalising the sector, as this marked a change where career education became mandatory and was integrated in the curriculum. In the most complex category 4 , a shift to a specified time allocation for career education as a standalone subject within the curriculum was discerned.

\section{Discussion}

In exploring career experts' conceptions of innovation in career development, this study identified four distinct categories of description that ranged from initiating service to exploiting cross-sectoral synergies. Six dimensions of variation were identified among the categories of description: innovative initiatives, development emphasis, rationale for developing ICT, continuing professional development, delivery of professional development and realisation of career education. While these findings generally align with earlier evidence, the present study also provides some new insights into career experts' conceptions of innovation.

Most of the similarities to earlier studies (e.g. Amundson, 2005; Barns et al., 2020; European Commission, 2011) relate mainly to the first three categories, in which innovation in career development is conceived as initiating service, developing demographic-based programmes, and professionalising the careers sector. Like Windrum and Koch (2008) and Amundson (2005), findings in this study confirm an increased emphasis on efficacy, as well as the increasing role of ICT in career services (Kettunen \& Sampson, 2019) and differences in systems of continuous professional development (OECD, 2004), including how that training is delivered (Cedefop, 2009). The findings also support earlier dominant vision that in public services 
innovation is a still often top-down process, which is initiated by political decisions (European Commission, 2011). In the most complex category, there is a discernible shift of emphasis towards a more collective cross-sectoral approach (e.g. Barns et al., 2020), accelerating collaborative innovation (Bommert, 2010; Torfing, 2019) to address common challenges at country level. These initiatives seek to ensure high-quality career services, with more efficient use of ICT, sustained continuing professional development programmes provided fully online and career education as a timetabled subject. Innovations are shaped through exploitation of cross-sectoral synergies. In practice, this necessitates new kinds of methods, which strengthen horizontal approaches and steering mechanisms that are adaptive to enable to respond to the rapidly changing situations.

In exploring the logical relationships between these qualitatively different conceptions of innovation, this study clarifies some key differences in career service delivery across 33 countries. The matrix presented in this article may serve as a catalyst for discussion of current and future trends. By increasing awareness and knowledge of the differences between the categories and dimensions of variation, we can stimulate dialogue that may play important role in improving innovation in career development.

The present study has some limitations. The ICCDPP symposium and this study were designed with a particular scope. The delimiting factor for the current study was the symposium's general focus on ensuring access, integration and innovation. Participation of country teams was voluntary, and data collected at a single timepoint may not fully represent the critical factors for the entire career service sector. While the study provides a recent overview of experts' conceptions of innovation in career service delivery, further studies are recommended in light of service changes precipitated by the onset of COVID-19. Has the COVID-19 pandemic accelerated or constrained innovation in career service delivery? The widespread transformation of in-person career services to distance services as practitioners worked remotely when offices were closed may have accelerated innovation, while the inevitable public sector budget cuts from a shrinking economy may have constrained innovation. Crisis often forces organisations to think outside the box. Dealing with pandemics, armed conflicts, and natural disasters may potentially influence the rate of innovation.

Funding Open access funding provided by University of Jyväskylä (JYU).

Open Access This article is licensed under a Creative Commons Attribution 4.0 International License, which permits use, sharing, adaptation, distribution and reproduction in any medium or format, as long as you give appropriate credit to the original author(s) and the source, provide a link to the Creative Commons licence, and indicate if changes were made. The images or other third party material in this article are included in the article's Creative Commons licence, unless indicated otherwise in a credit line to the material. If material is not included in the article's Creative Commons licence and your intended use is not permitted by statutory regulation or exceeds the permitted use, you will need to obtain permission directly from the copyright holder. To view a copy of this licence, visit http://creativecommons.org/licen ses/by/4.0/. 


\section{References}

Åkerlind, G. (2005a). Learning about phenomenography: Interviewing, data analysis and qualitative research paradigm. In J. A. Bowden \& P. Green (Eds.), Doing developmental phenomenography (pp. 63-73). RMIT University Press.

Åkerlind, G. S. (2005b). Variation and commonality in phenomenographic research methods. Higher Education Research \& Development, 24, 321-334. https://doi.org/10.1080/07294360500284672

Åkerlind, G., Bowden, J. A., \& Green, P. (2005). Learning to do phenomenography: A reflective discussion. In J. A. Bowden \& P. Green (Eds.), Doing developmental phenomenography (pp. 74-100). RMIT University Press.

Amundson, N. (2005). The potential impact of global changes in work for career theory and practice. International Journal for Educational and Vocational Guidance, 5, 91-99. https://doi.org/10.1007/ s10775-005-8787-0

Barnes, S.-A., Bimrose, J., Brown, A., Kettunen, J., \& Vuorinen, R. (2020). Lifelong guidance policy and practice in EU: Trends, challenges and opportunities. European Commission.

Bimrose, J., Barnes, S.-A., \& Atwell, G. (2010). An investigation into the skills needed by Connexions Personal Advisers to develop internet-based guidance. CfBT Education Trust.

Bommert, B. (2010). Collaborative innovation in the public sector. International Public Management Review, 11(1), 15-33.

Bowden, J. (2000a). Experience of phenomenographic research. A personal account. In J. Bowden \& E. Walsh (Eds.), Phenomenography (pp. 47-61). Royal Melbourne Institute of Technology.

Bowden, J. (2000b). The nature of phenomenographic research. In J. Bowden \& E. Walsh (Eds.), Phenomenography (pp. 1-18). Royal Melbourne Institute of Technology.

Bowden, J., \& Green, P. (Eds.). (2005). Doing developmental phenomenography. RMIT University Press.

Bowden, J. A., \& Green, P. J. (2010). Relationality and the myth of objectivity in research involving human participants. In J. Higgs, N. Cherry, R. Macklin, \& R. Ajjawi (Eds.), Researching practiceA discourse on qualitative methodologies (pp. 105-121). Sense Publishers.

Bowden, J. A., \& Walsh, E. (2000). Phenomenography. RMIT University Press.

Brynjolfsson, E., \& McAfee, A. (2014). The second machine age: Work, progress, and prosperity in a time of brilliant technologies. W. W. Norton and Company.

Cedefop. (2009). Professionalising career guidance: Practitioner competences and qualification routes in Europe. Cedefop panorama series 164. Office of the European Union.

Cedefop. (2011). Lifelong guidance across Europe: Reviewing policy progress and future prospects. Publications Office of the European Union.

Cedefop. (2016). Future skills need in Europe: Critical labour force trends. Publications Office of the European Union.

Dasgupta, M., \& Gupta, R. K. (2009). Innovation in organizations: A review of the role of organizational knowledge management. Global Business Review, 10, 203-224. https://doi.org/10.1177/09721 5090901000205

Dølvik, J. E., \& Steen, J. R. (2018). The Nordic future of work. Drivers, institutions and politics. Nordic Council of Ministers. https://doi.org/10.6027/TN2018-555

Drobnik, J. (2019). The key innovations in career guidance on labour market. Economics Ecology Socium, 3(2), 12-22. https://doi.org/10.31520/2616-7107/2019.3.2-2

Eurofound. (2017). Occupational change and wage inequality: European jobs monitor 2017. Publications Office of the European Union.

European Commission (2011). Innobarometer 2010: Analytical report on innovation in public administration (Flash Eurobarometer 305). DG Enterprise. https://ec.europa.eu/commfrontoffice/publicopin ion/flash/fl_305_en.pdf

European Council. (2004). Draft resolution of the council and of the representatives of the member states meeting within the council on strengthening policies, systems and practices in the field of guidance throughout life in Europe. Council of the European Union, 18 May 2004.

European Council. (2008). Draft resolution of the council and of the representatives of the government of the member states, meeting within the council, on better integrating lifelong guidance into lifelong learning strategies.

Flederman, P., \& Watts, A. G. (2014). Career helplines: A resource for career development. In G. Arulmani, A. J. Bakshi, F. T. L. Leong, \& A. G. Watts (Eds.), International and cultural psychology. 
Handbook of career development: International perspectives (pp. 481-493). Springer. https://doi. org/10.1007/978-1-4614-9460-7_27

Frey, C. B., \& Osborne, M. A. (2017). The future of employment: How susceptible are jobs to computerisation? Technological Forecasting and Social Change, 114, 254-280. https://doi.org/10.1016/j.techf ore.2016.08.019

Hartley, J. (2005). Innovation in governance and public services: Past and present. Public Money and Management, 25, 27-34. https://doi.org/10.1111/j.1467-9302.2005.00447.x

Hathaway, T., \& Fletcher, P. (2018). An investigation of K-6 pre-service teachers' ways of experiencing the teaching of diverse learners using phenomenography. Educational Research for Policy and Practice, 17, 83-104. https://doi.org/10.1007/s10671-017-9220-4

Hautamäki, A., \& Oksanen, K. (2016). Sustainable innovation: Solving wicked problems through innovation. In A.-L. Mention \& M. Torkkeli (Eds.), Open innovation: A multifaceted perspective (pp. 87-110). World Scientific. https://doi.org/10.1142/9789814719186_0005

Hirschi, A. (2018). The fourth industrial revolution and implications for career research and practice. The Career Development Quarterly, 66, 192-204. https://doi.org/10.1002/cdq.12142

Hooley, T., Hutchinson, J., \& Watts, A. G. (2010). Careering through the web. The potential of Web 2.0 and 3.0 technologies for career development and career support services. UK Commission for Employment and Skills.

International Labour Organization. (2016). Non-standard employment around the world: Understanding challenges, shaping prospects. International Labour Organization.

Kettunen, J. (2017). Career practitioners' conceptions of social media and competency for social media in career services. University of Jyväskylä.

Kettunen, J., \& Makela, J. P. (2019). Practitioners' conceptions of ethical practice in social networking in career services. International Journal Educational and Vocational Guidance, 19, 345-362. https:// doi.org/10.1007/s10775-018-9383-4

Kettunen, J., \& Sampson, J. P., Jr. (2019). Challenges in implementing ICT in career services: Perspectives from career development experts. International Journal for Educational and Vocational Guidance, 19, 1-18. https://doi.org/10.1007/s10775-018-9365-6

Kettunen, J., \& Tynjälä, P. (2018). Applying phenomenography in guidance and counselling research. British Journal of Guidance \& Counselling, 46, 1-11. https://doi.org/10.1080/03069885.2017. 1285006

Kettunen, J., Vuorinen, R., \& Ruusuvirta, O. (2016). European Lifelong Guidance Policy Network representatives' conceptions of the role of information and communication technologies related to national guidance policies. International Journal for Educational and Vocational Guidance, 16, 327-342. https://doi.org/10.1007/s10775-015-9313-7

Kettunen, J., Vuorinen, R., \& Sampson, J. P. (2013). Career practitioners' conceptions of social media in career services. British Journal of Guidance \& Counselling, 41, 302-317. https://doi.org/10.1080/ 03069885.2013 .781572

Kettunen, J., Vuorinen, R., \& Sampson, J. P. (2015). Practitioners' experiences of social media in career services. The Career Development Quarterly, 63, 268-282.

Lee, F. K., \& Johnston, J. A. (2001). Innovation in career counseling. Journal of Career Development, 27(3), 177-185. https://doi.org/10.1177/089484530102700304

Loughland, T., Reid, A., \& Petocz, P. (2002). Young people's conceptions of environment: A phenomenographic analysis. Environmental Education Research, 8, 187-197. https://doi.org/10.1080/13504 620220128248

Marton, F. (1981). Phenomenography: Describing conceptions of the world around us. Instructional Science, 10, 177-200.

Marton, F. (1986). Phenomenography-A research approach investigating different understandings of reality. Journal of Thought, 21, 28-49.

Marton, F., \& Booth, S. (1997). Learning and awareness. Lawrence Erlbaum Associates.

Marton, F., \& Pong, Y. W. (2005). On the unit of description in phenomenography. Higher Education Research \& Development, 24, 335-348. https://doi.org/10.1080/07294360500284706

McMahon, M., \& Tatham, P. (2008). Career: More than just a job. education.au limited.

Mulvey, R. (2013). How to be a good professional: Existentialist continuing professional development (CPD). British Journal of Guidance and Counselling, 41, 267-276. https://doi.org/10.1080/03069 885.2013 .773961

Nykänen, S. (2011). Towards leadership and management in guidance and counselling networks in Finland. University of Jyväskylä. 
Organization for Economic Co-Operation and Development. (2004). Career guidance and public policy: Bridging the gap. Organization for Economic Co-Operation and Development.

Organization for Economic Co-Operation and Development. (2010). Learning for jobs. https://doi.org/10. 1787/9789264087460-5-en

Organization for Economic Co-Operation and Development. (2019). OECD Employment outlook 2019: The future of work. https://doi.org/10.1787/9ee00155-en

Patton, W., \& McMahon, M. (2015). Career development and systems theory: Connecting theory and practice (3rd ed.). Sense Publishers.

Pittaway, L., Robertson, M., Munir, K., Denyer, D., \& Neely, A. (2004). Networking and innovation: A systematic review of the evidence. International Journal of Management Review, 5/6(3/4), 108-117. https://doi.org/10.1111/j.1460-8545.2004.00101.x

Sampson, J. P., Jr., Kettunen, J., \& Vuorinen, R. (2020). The role of practitioners in helping persons make effective use of ICT in career interventions. International Journal for Educational and Vocational Guidance, 20, 191-208. https://doi.org/10.1007/s10775-019-09399-y

Savickas, M. L., Nota, L., Rossier, J., Dauwalder, J., Duarte, M., Guichard, J., Soresi, S., van Esbroeck, R., \& van Vianen, A. (2009). Life designing: A paradigm for career construction in the 21 st century. Journal of Vocational Behaviour, 75, 239-250. https://doi.org/10.1016/j.jvb.2009.04.004

Sienkiewicz, L. (2012). Job profiles and training for employment counsellors. European Commission.

Torfing, J. (2019). Collaborative innovation in the public sector: The argument. Public Management Review, 21, 1-11. https://doi.org/10.1080/14719037.2018.1430248

Tynjälä, P. (1997). Developing education students' conceptions of the learning process in different learning environments. Learning \& Instruction, 7, 277-292. https://doi.org/10.1016/S0959-4752(96) 00029-1

Van de Ven, A. H. (1986). Central problems in the management of innovation. Management Science, 32, 590-607. https://doi.org/10.1287/mnsc.32.5.590

Van der Vegt, G., \& Janssen, O. (2003). Joint impact of interdependence and group diversity on innovation. Journal of Management, 29, 729-751. https://doi.org/10.1016/S0149-2063(03)00033-3

Van Reenen, J., Bloom, N., Draca, M., Kretschmer, T., Sadun, R., Overman, H., \& Schankerman, M. (2010). The economic impact of ICT. Final Report, Centre for Economic Performance, London School of Economics.

Watts, A. G., Bezanson, L., \& McCarthy, J. (2014). International symposia on career development and policy: Retrospect and prospect. Australian Journal of Career Development, 23, 108-117. https:// doi.org/10.1177/103841621453390

Watts, T. (2005). Career guidance policy: An international review. Career Development Quarterly, 54(1), 66-76. https://doi.org/10.1002/j.2161-0045.2005.tb00142.x

Windrum, P., \& Koch, P. (2008). Innovation in public sector services. Edward Elgar.

Zelloth, H. (2009). In demand: Career guidance in EU neighbouring countries. Office for Official Publications of the European Communities.

Publisher's Note Springer Nature remains neutral with regard to jurisdictional claims in published maps and institutional affiliations. 